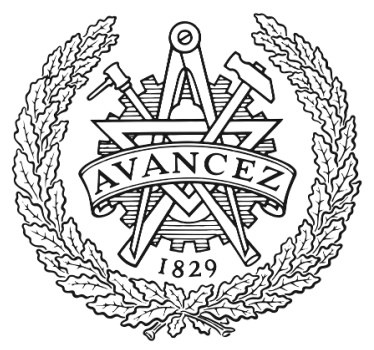

CHALMERS

UNIVERSITY OF TECHNOLOGY

\title{
Glycerol to lactic acid conversion by NHC-stabilized iridium nanoparticles
}

Downloaded from: https://research.chalmers.se, 2023-04-26 02:58 UTC

Citation for the original published paper (version of record):

Oberhauser, W., Evangelisti, C., Liscio, A. et al (2018). Glycerol to lactic acid conversion by

NHC-stabilized iridium nanoparticles. Journal of Catalysis, 368: 298-305.

http://dx.doi.org/10.1016/j.jcat.2018.10.024

N.B. When citing this work, cite the original published paper. 


\title{
Glycerol to lactic acid conversion by NHC-stabilized iridium nanoparticles
}

\author{
Francesco Vizza ${ }^{a}$ \\ ${ }^{a}$ Istituto di Chimica dei Composti Organometallici (CNR-ICCOM), Via Madonna del Piano 10, 50019 Sesto Fiorentino, Italy \\ ${ }^{\mathrm{b}}$ Istituto di Scienze e Tecnologie Molecolari (CNR-ISTM), Via Fantoli 16/15, 20138 Milano, Italy \\ ' Istituto per la Sintesi Organica e la Fotoreattività (CNR-ISOF), Via Gobetti 101, 40129 Bologna, Italy \\ ${ }^{\mathrm{d}}$ Istituto per la Microelettronica e Microsistemi (CNR-IMM), Via del Fosso del Cavaliere 100, 00133 Roma, Italy \\ e Department of Industrial and Materials Science, Chalmers University of Technology, SE-412 96 Göteborg, Sweden
}

Werner Oberhauser ${ }^{\mathrm{a}, *}$, Claudio Evangelisti $^{\mathrm{b}}$, Andrea Liscio ${ }^{\mathrm{c}, \mathrm{d}}$, Alessandro Kovtun ${ }^{\mathrm{c}}, \mathrm{Yu}_{\mathrm{Cao}}^{\mathrm{e}}$,

\section{A R T I C L E I N F O}

\section{Article history:}

Received 29 August 2018

Revised 12 October 2018

Accepted 13 October 2018

\section{Keywords:}

Iridium nanoparticles

NHC-ligand

Glycerol

Lactic acid

1,4-Dioxane

\begin{abstract}
A B S T R A C T
Hydrogen reduction of an $\operatorname{Ir}(\mathrm{I})$ complex featured by a bulky $\mathrm{N}$-heterocyclic carbene (NHC) ligand in dichloromethane gave small-sized $(1.8 \mathrm{~nm})$ Ir nanoparticles (NPs) decorated with NHC ligands $\left(\mathrm{Ir}^{\mathrm{NHC}}\right)$. 1,4-Dioxane solutions of the latter particles were successfully applied to convert glycerol into lactic acid in the presence of $\mathrm{NaOH}$ (i.e. 1 mol equivalent with respect to glycerol). $\mathrm{Ir}^{\mathrm{NHC}}$ showed an atom-related TOF value of almost $10^{4} \mathrm{~h}^{-1}$, an almost exclusive formation of liquid reaction products, a high selectivity for lactic acid (93.0\%) and a complete recyclability in air atmosphere. Attempts to synthesize analogous NHC-stabilized Ir NPs on a high surface area carbon support $\left(C^{K}\right)$ by reducing the same $\operatorname{Ir}(\mathrm{I})$ precursor, supported onto $C^{\mathrm{K}}$, prior to the hydrogen reduction in water, gave almost naked $C^{\mathrm{K}}$-supported Ir NPs $(1.4 \mathrm{~nm})$. Their catalytic activity tested for the same reaction in water as reaction medium, exhibited much lower catalytic activity $\left(4 \times 10^{3} \mathrm{~h}^{-1}\right)$, a lower percentage of liquid reaction products (i.e. $27.0 \%$ of the converted glycerol) and a lower selectivity for lactic acid compared to $\mathrm{Ir}^{\mathrm{NHC}}$.
\end{abstract}

(c) 2018 Elsevier Inc. All rights reserved.

\section{Introduction}

Lactic acid (LA) is an important organic platform molecule used to be converted to lactate ester, propylene glycol, 2,3pentanedione, propanoic acid, acrylic acid, acrolein, acetaldehyde and lactide [1]. The latter mainly used for the synthesis of poly(lactic acid), an important bioplastic material $[1,2]$. One pot catalytic syntheses of LA from glycerol (GLY) (i.e. obtained from biodiesel production [3]) give hydrogen as reaction product, obtained under acceptorless dehydrogenation reaction conditions [4-8]. Highly active $\mathrm{Ru}-[9]$ and Ir-based [10,11] molecular catalysts were employed to convert GLY to LA under acceptorless catalytic conditions, obtaining a LA selectivity of $96 \%$. All successfully employed molecular $\operatorname{Ir}(\mathrm{I})$ catalysts are stabilized by $\mathrm{N}$-heterocyclic carbene (NHC)-ligands, which are known to be suitable ligands for transition metals occurring in different oxidation states. Their suitability as ligands is due to: $(i)$ their electron donor property, leading hence to strong metal-ligand bonds; (ii) their steric properties, which can be simply modified by substituting the nitrogen atoms in 1,3-

\footnotetext{
* Corresponding author.

E-mail address: werner.oberhauser@iccom.cnr.it (W. Oberhauser).
}

position of the imidazol-based ring with the desired substituent and (iii) their stability under oxidizing reaction conditions $[12,13]$. In addition, the variable bulkiness of the NHC-ligands has found to be exploitable for the stabilization of metalnanoparticles (NPs) of different size. As a result, an increasing steric bulk of the NHC ligand leads to the stabilization of small NPs [14-19]. NHC-decorated metal NPs have been synthesized by either ligand exchange reactions (i.e. ligand-stabilized metal NP reacts with the desired in situ generated NHC ligand) $[14,20]$ or by decomposition of an NHC-containing organometallic species [15-17,21,22]. An Ir $_{6}$-polyhydride cluster containing NHC-ligands (i.e. $\mathrm{NHC}=1,3$-dimethylimidazol-2-ylidene) has been obtained and isolated from a catalytic GLY to LA conversion, proving the decomposition of $\operatorname{Ir}(\mathrm{I})-\mathrm{NHC}$ organometallic species under real catalytic conditions [23]. Similar observations were made with $\operatorname{Ir}(\mathrm{I})$ mono NHC complexes used for the hydrogen-transfer reactions of GLY bringing about the formation of Ir NPs [24].

Recently, Tu immobilized an Ir(I)-NHC species by a supramolecular assembly approach, obtaining a highly efficient (LA selectivity up to 98\%) and recyclable catalyst (up to 30 times) [25]. Heterogeneous catalysts employed for the GLY to LA conversion are metal nanoparticle (NP)-based [26] and GLY conversions under acidic 
(Lewis or Brønsted acid) [27-30] and basic [31-38] reaction conditions were reported. Bimetallic Au-Pt NPs supported onto $\mathrm{CeO}_{2}$ were found to be very efficient catalysts for GLY to LA conversion reaching TOF values of $1350 \mathrm{~h}^{-1}$ and a chemoselectivity of $80 \%$ at $100{ }^{\circ} \mathrm{C}$ [32] with the main drawback that the reaction has to be conducted under oxygen pressure $(72.5 \mathrm{psi}$ ) and a high $\mathrm{NaOH} /$

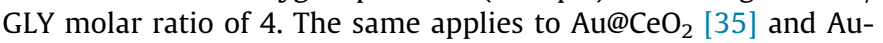
Pt@TiO ${ }_{2}$ [31]. In this context iridium-based NPs are efficient also in the absence of an hydrogen acceptor and do not require an excess of inorganic base [34].

Herein we report for the first time the synthesis of unsupported Ir NPs, stabilized by a bulky NHC ligand through a controlled decomposition of an $\operatorname{Ir}(\mathrm{I})-\mathrm{NHC}$ precursor under a hydrogen atmosphere. In order to prove, if the same type of Ir NPs could be obtained on a support by hydrogen reduction of the same supported $\operatorname{Ir}(\mathrm{I})-\mathrm{NHC}$ precursor, we have chosen a carbon support characterized by a high surface area $\left(1400 \mathrm{~m}^{2} / \mathrm{g}\right)$ in order to avoid crystallization of the organometallic compound during the deposition step [39] upon maximizing the dispersion of the supported Ir (I)-NHC compound on the support prior to reduction with hydrogen. The obtained Ir NPs were then tested as catalyst for the conversion of GLY to LA under basic reactions conditions.

\section{Experimental section}

\subsection{Materials}

Glycerol (GLY) 1,2-propandiol (1,2-PD), [ $\operatorname{IrCl}(\mathrm{COD})]_{2}$ (COD = 1,5cyclooctadiene), 1,4-dioxane and $\mathrm{NaOH}$ were purchased from Aldrich and used as received. Water was bidistilled. Ketjenblack EC-600JD ( $\left.\mathrm{C}^{\mathrm{K}}\right)\left(1400 \mathrm{~m}^{2} / \mathrm{g}\right)$ [39] was purchased from Cabot Corp. USA. [ $\left.\operatorname{IrCl}(\mathrm{COD})\left(\mathrm{L}^{\mathrm{NHC}}\right)\right]$ with $\mathrm{L}^{\mathrm{NHC}}=1,3$-bis $((2,6-\mathrm{di}$-isopropyl $)$ phe nyl)imidazol-2-ylidene was synthesized according to a reported synthesis protocol [40]. Dichloromethane was distilled over $\mathrm{CaH}_{2}$ in a nitrogen atmosphere. $\mathrm{CDCl}_{3}$ used for NMR characterization was purchased from Aldrich and used without further treatment.

\subsection{Catalysts' synthesis}

\subsubsection{Unsupported Ir NPS (Ir ${ }^{N H C}$ and Ir ${ }^{\text {black }}$ )}

A deaerated $\mathrm{CH}_{2} \mathrm{Cl}_{2}$ solution $(30.0 \mathrm{~mL})$ of $\left[\mathrm{IrCl}(\mathrm{COD})\left(\mathrm{L}^{\mathrm{NHC}}\right)\right]$ $(60.0 \mathrm{mg})$ was transferred under a nitrogen atmosphere into an evacuated teflonated stainless steel autoclave by suction. Afterwards the autoclave was pressurized (150 psi) with hydrogen, followed by heating the autoclave to $373 \mathrm{~K}$ and adjusting the hydrogen pressure to $435 \mathrm{psi}$. The autoclave was continued to heat by means of an oil bath for three hours. The autoclave was then cooled to $283 \mathrm{~K}$, the hydrogen gas carefully vented off and the clear brown solution transferred into a Schlenk tube under nitrogen atmosphere. The obtained solution was analyzed by GC-MS and the solvent evaporated by means of a vacuum pump. A portion of the obtained brown powder ( $\mathrm{Ir}^{\mathrm{NHC}}$ ) was dissolved in $\mathrm{CDCl}_{3}$, followed by the acquisition of ${ }^{1} \mathrm{H}$ and ${ }^{13} \mathrm{C}\left\{{ }^{1} \mathrm{H}\right\}$ NMR spectra at room temperature, while the other portion was used for powder X-ray analysis. The same synthesis protocol was applied when $[\mathrm{IrCl}$ (COD) $]_{2}$ was used as $\operatorname{Ir}(\mathrm{I})$ precursor. The obtained black precipitate ( $\left.\mathrm{Ir}^{\text {black}}\right)$ was separated from solution by decantation, dried under vacuum and used to acquire a powder X-ray spectrum.

\subsubsection{Carbon-supported Ir NPs (Ir $@ C^{K}$ and $\left.I r^{2} @ C^{K}\right)$}

Ketjenblack $\left(\mathrm{C}^{\mathrm{K}}\right)(1.70 \mathrm{~g})$ was suspended in distilled $\mathrm{CH}_{2} \mathrm{Cl}_{2}$ $(200.0 \mathrm{~mL})$ upon magnetic stirring for one hour at room temperature in a nitrogen atmosphere. Then a solution of $\left[\mathrm{IrCl}(\mathrm{COD})\left(\mathrm{L}^{\mathrm{NHC}}\right)\right]$ (70.8 mg, $97.79 \mu \mathrm{mol})$ in $\mathrm{CH}_{2} \mathrm{CL}_{2}(20.0 \mathrm{~mL})$ was added to the black $\mathrm{C}^{\mathrm{K}}$-suspension, which was continued to stir for $3 \mathrm{~h}$ at room temperature in a nitrogen atmosphere. The solvent was then completely removed and the black residue dried at room temperature by means of a vacuum pump until the weight of the isolated solid $\left(\left[\mathrm{IrCl}(\mathrm{COD})\left(\mathrm{L}^{\mathrm{NHC}}\right)\right] @ \mathrm{C}^{\mathrm{K}}\right)$ was constant. The latter solid $(1.50 \mathrm{~g})$ was then placed in a stainless steel autoclave, which was evacuated and deaerated water $(50.0 \mathrm{~mL})$ was introduced by suction. The autoclave was then heated to $418 \mathrm{~K}$, charged with hydrogen (769 psi) and stirred for three hours. Afterwards, the autoclave was cooled to room temperature, excess hydrogen vented off, the suspension centrifuged and the black solid $\left(\operatorname{Ir}^{1} @ C^{K}\right)$ dried in a vacuum oven at $323 \mathrm{~K}$ until the weight of the isolated solid was constant. An identical synthesis protocol was applied to synthesize $\operatorname{Ir}^{2} @ C^{K}$, using $[\operatorname{IrCL}(C O D)]_{2}$ as $\operatorname{Ir}(\mathrm{I})$ source.

\subsection{Catalysts' characterization}

${ }^{1} \mathrm{H}$ and ${ }^{13} \mathrm{C}\left\{{ }^{1} \mathrm{H}\right\}$ NMR spectra of $\mathrm{CDCl}_{3}$ solutions of $\mathrm{Ir}^{\mathrm{NHC}}$ were acquired at room temperature using a Bruker Avance $400 \mathrm{MHz}$ spectrometer at 400.12 and $100.01 \mathrm{MHz}$, respectively.

Powder X-ray diffraction (PXRD) spectra were acquired at room temperature with a PANalytical X'PERT PRO powder diffractometer, employing $\mathrm{Cu} \mathrm{K}_{\alpha}$ radiation $(\lambda=1.5418 \AA)$ and a parabolic MPD-mirror, in the $2 \Theta$ range from 3.0 to $75.0^{\circ}$. The Ir-NPs' size was estimated applying the Debye-Scherrer-method [41].

Transmission electron microscopic (TEM) analysis of the NHCstabilized Ir-NPs was carried out with a ZEISS LIBRA 200FE, equipped with a $200 \mathrm{kV}$ FEG source, in column second generation omega filter, HAADF STEM high angular annular dark field scanning transmission electron microscopy) facility, and Energydispersive X-ray (EDX) probe (Oxford INCA Energy TEM 200) for chemical analysis. The carbon supported catalysts were ultrasonically dispersed in iso-propanol and a drop of the solution was deposited on a lacey-carbon film supported on a copper TEM grid of 300 mesh. The unsupported Ir-NPs ( $\mathrm{Ir}^{\mathrm{NHC}}$ ) were dispersed in 1,4-dioxane and a drop of the solution was deposited on a lacey-carbon film supported on a copper TEM grid of 300 mesh. Histograms of the particle size distribution were obtained by counting at least 500 particles. The mean particle diameter $\left(d_{m}\right)$ was calculated by using the formula $\mathrm{d}_{\mathrm{m}}=\Sigma \mathrm{d}_{\mathrm{i}} \mathrm{n}_{\mathrm{i}} / \Sigma \mathrm{n}_{\mathrm{i}}$ where $\mathrm{n}_{\mathrm{i}}$ is the number of particles with diameter $d_{i}$. The percentages of surface atoms were determined from TEM histograms using calculations reported for close to sphere-shaped NPs) [42]. As a result we obtained for $\mathrm{Ir}^{\mathrm{NHC}}, \mathrm{Ir}^{1} @ \mathrm{C}^{\mathrm{K}}$ and $\mathrm{Ir}^{2} @ \mathrm{C}^{\mathrm{K}}$ a surface atom percentage of $52.0,65.0$ and $67.0 \%$, respectively.

X-ray Photoelectron Spectroscopy (XPS) was carried out by using a PHI 5500 instrument (Perkin Elmer, Waltham, Massachusetts, USA), with monochromatic Al $\mathrm{K}_{\alpha}$ source $(1486.6 \mathrm{eV})$ and the analyzed area had a diameter of $0.8 \mathrm{~mm}$. The base pressure in the analysis chamber was ca. $10^{-9}$ mbar. The samples (powder) were mounted on a carbon tape prior to analysis. The acquisition conditions for such high-resolution spectra were $23.5 \mathrm{eV}$ pass energy with the step of $0.1 \mathrm{eV}$ and a nominal take-off angle of $45^{\circ}$. All spectra were calibrated on C $1 \mathrm{~s}(284.4 \mathrm{eV})$. The recorded photoelectron peaks were curve fitted using the CasaXPS software and assuming a Shirley background. Survey spectra and selected region spectra were recorded: Ir $4 \mathrm{f}, \mathrm{N} 1 \mathrm{~s}, \mathrm{O} 1 \mathrm{~s}$ and $\mathrm{C} 1 \mathrm{~s}$. Ir $4 \mathrm{f}$ spectra were fitted with 2 doublet peaks: $\operatorname{Ir}(0)$ and $\operatorname{Ir}(\mathrm{IV})$ was associated to the $4 \mathrm{f}_{7 / 2}$ binding energies (B.E.) of $60.8 \mathrm{eV}$ and $61.7 \mathrm{eV}$, respectively [43]. Asymmetric line-shape were used for both chemical states, since metal and oxide are both conductive [44]. The detailed explanation of the line-shape used is reported [45]. The XPS Ir $4 \mathrm{f}$ doublet $\left(4 \mathrm{f}_{5 / 2}\right.$ and $\left.4 \mathrm{f}_{7 / 2}\right)$ were fitted by fixing: ( $\left.i\right)$ the spin orbital energy split $(\Delta=3.0 \mathrm{eV})[44]$ and (ii) the ratio between the peak areas (3:4). All relevant fitting parameters are reported in Tables S2-S4. C 1s, O 1s and Si 2p XPS signals originated from the carbon support and carbon tape used represented more than $99 \%$ of the 
XPS signal. The relative quantity of Ir amounted to about 0.07$0.13 \%$. This low amount of Ir did not permit to detect the $\mathrm{N} 1 \mathrm{~s}$ signal (originating from the NHC-ligand) because of the low sensitivity factor of $\mathrm{N} 1 \mathrm{~s}$ (i.e. relative sensitivity factor for $\mathrm{N} 1 \mathrm{~s}$ is about 7 times lower than that for Ir 4f) [46]. The $\mathrm{O} 1 \mathrm{~s}$ peak is ascribable to oxygen stemming from water and oxygen containing functional groups present on $\mathrm{C}^{\mathrm{K}}$ support [39].

The iridium metal loading of the $C^{\mathrm{K}}$-supported Ir NPs were determined by ICP-OES (ICAP6300 Duo, purchased from Thermo Fisher Scientific) applying an external calibration methodology. The samples $(10.0 \mathrm{mg})$ were microwave digested $(5.0 \mathrm{~mL} \mathrm{HCl}$ $37 \%+\mathrm{H}_{2} \mathrm{O}_{2} 30 \%$ ) and diluted with highly deionized (Milli-Q Academic, Millipore) to a final weight of $10.0 \mathrm{~g}$. Iridium leaching was measured with the same procedure starting from $100.0 \mathrm{mg}$ of reaction solution (after catalysis), which was filtered $(0.2 \mu \mathrm{m})$ at the end of catalytic reaction. ICP-OES analyses carried out on isolated $\mathrm{Ir}^{1} @ \mathrm{C}^{\mathrm{K}}$ and $\mathrm{Ir}^{2} @ \mathrm{C}^{\mathrm{K}}$ revealed an Ir content of 0.77 and $0.94 \mathrm{wt} \%$, respectively.

\subsection{Catalytic performance test}

\subsubsection{Catalytic reactions in 1,4-dioxane}

Catalytic reactions with $\mathrm{Ir}^{\mathrm{NHC}}$ in 1,4-dioxane were carried out as follows: GLY (14.34 g, $156.0 \mathrm{mmol})$ and $\mathrm{NaOH}(6.24 \mathrm{~g}, 156.0 \mathrm{mmol})$ were placed in a stainless steel autoclave $(320.0 \mathrm{~mL})$, which was sealed and evacuated. Then a solution of $\operatorname{Ir}^{\mathrm{NHC}}(\mathrm{Ir}, 5.65 \mu \mathrm{mol})$ in deaerated 1,4-dioxane $(30.0 \mathrm{~mL})$ was added by suction. The autoclave was then heated under vigorous mechanically stirring at $418 \mathrm{~K}$ for the desired reaction time, followed by cooling to $283 \mathrm{~K}$ by means of an ice water mixture. Then the gas formed was released and collected in a burette for GC-analysis, whereas the 1,4-dioxane solution was decanted and the highly viscous residue solubilized in water. The water phase was acidified to $\mathrm{pH}=7$ by adding $\mathrm{H}_{2} \mathrm{SO}_{4}$. The 1,4-dioxane and acidified water solutions were subjected to HPLC analysis. Recycling experiments were performed by using the recovered 1,4-dioxane solution and a new portion of GLY.

\subsubsection{Catalytic reactions in water}

Catalytic reactions with $\mathrm{Ir}^{1} @ \mathrm{C}^{\mathrm{K}}$ and $\mathrm{Ir}^{2} @ \mathrm{C}^{\mathrm{K}}$ in water were carried out as follows: The solid catalysts (Ir, $5.65 \mu \mathrm{mol}$ ) were placed in a stainless steel autoclave $(320.0 \mathrm{~mL})$, which was sealed an evacuated. Then a deaerated water solution $(30.0 \mathrm{~mL})$ of GLY (14.34 g, $156.0 \mathrm{mmol})$ and $\mathrm{NaOH}(6.24 \mathrm{~g}, 156.0 \mathrm{mmol})$ was introduced in the autoclave by suction, which was then heated to $418 \mathrm{~K}$ and mechanically stirred $(900 \mathrm{rpm})$ for the desired reaction time. The autoclave was then cooled to $283 \mathrm{~K}$ by means of a water ice bath, the gas formed collected in a burette and the suspension centrifuged. The recovered catalyst was washed several times $(\mathrm{pH}=7)$ and then dried in a vacuum oven at $323 \mathrm{~K}$ to constant weight. The water solution was cooled to $283 \mathrm{~K}$, acidified with sulfuric acid to $\mathrm{pH}=1$ and analyzed by HPLC. Recycling experiments with recovered $\mathrm{Ir}^{1} @ \mathrm{C}^{\mathrm{K}}$ and $\mathrm{Ir}^{2} @ \mathrm{C}^{\mathrm{K}}$ were performed following the above described experimental procedure.

\subsection{Analysis of the reaction products}

\subsubsection{Analysis of the liquid reaction products}

The acidified catalytic water solutions $(\mathrm{pH}=1)$ were filtered by a paper filter in order to remove precipitated $\mathrm{Na}_{2} \mathrm{SO}_{4}$, while 1,4dioxane solutions were analyzed without further treatment. Both solutions (1,4-dioxane and water) were analyzed by HPLC using a Shimadzu-UFLC apparatus, equipped with a RID detector and a Alltech OA-1000 organic acid column of $300 \mathrm{~mm}$ (length) and a $6.5 \mathrm{~mm}$ (i.d.); $0.01 \mathrm{~N} \mathrm{H}_{2} \mathrm{SO}_{4}$ was used as eluent with a flow rate of $0.4 \mathrm{~mL} / \mathrm{min}$ at $338 \mathrm{~K}$. The percentage of GLY conversion, the surface-related TOF values and the percentage of the selectivity of the liquid reaction products were calculated as follows:

GLY conversion $(\%)=100 \times\left[\operatorname{mmol}\left(G_{\text {initial }}\right)-\operatorname{mmol}\left(\mathrm{GLY}_{\text {unreacted }}\right)\right] / \mathrm{mmol}\left(\mathrm{GLY}_{\text {initial }}\right)$

$\mathrm{TOF}=\mathrm{mmol}\left(\mathrm{GLY}_{\text {converted }}\right) /\left[\mathrm{mmol}\left(\mathrm{Ir}_{\text {surface }}\right) \times \mathrm{h}\right] ; \mathrm{mmol}\left(\mathrm{Ir}_{\text {surface }}\right)$ $=2.91 \times 10^{-3}\left(\mathrm{Ir}^{\mathrm{NHC}}\right) ; 3.64 \times 10^{-3}\left(\operatorname{Ir}^{1} @ \mathrm{C}^{\mathrm{K}}\right)$ and $3.75 \times 10^{-3}\left(\mathrm{Ir}^{2} @ \mathrm{C}^{\mathrm{K}}\right)$.

Selectivity (liquid prod.) $(\%)=100 \times \mathrm{mmol}(\operatorname{prod}) /[\mathrm{mmol}(\mathrm{LA})$ $+\operatorname{mmol}(1,2 \mathrm{PD})+\operatorname{mmol}(\mathrm{FA})+\operatorname{mmol}(\mathrm{EG})] ;$ lacticacid $(\mathrm{LA}), 1,2$ - propandiol(1,2PD), formicacid(FA)andethyleneglycol(EG).

\subsubsection{Analysis of the gaseous reaction products}

After the catalytic reactions, the autoclave was cooled to $283 \mathrm{~K}$ and the gas phase analyzed off-line using a gas tight syringe. The GC used was a Shimadzu GC 2010 apparatus, equipped with a TCD and a fused silica capillary column (Supelco Carboxen 1010 PLOT $(30.0 \mathrm{~mm} \times 0.32 \mathrm{~mm}$ ). Helium was used as carrier gas and the following temperature program was utilized for the analysis: $413 \mathrm{~K}$ for 9 min followed by a heating ramp of $30 \mathrm{~K}$ per minute up to $498 \mathrm{~K}$ and lasting this latter temperature for $30 \mathrm{~min}$.

\section{Results and discussion}

\subsection{Catalysts' synthesis}

We synthesized unsupported Ir NPs reduction of $[\mathrm{IrCl}(\mathrm{COD})$ $\left.\left(\mathrm{L}^{\mathrm{NHC}}\right)\right][40]$ and $[\mathrm{IrCl}(\mathrm{COD})]_{2}$ in $\mathrm{CH}_{2} \mathrm{Cl}_{2}$ at $373 \mathrm{~K}$ in the presence of hydrogen pressure (435 psi) (Scheme 1 ).

As a result, a clear brown dichloromethane solution of $\mathrm{Ir}^{\mathrm{NHC}}$ was obtained when $\left[\operatorname{IrCl}(\mathrm{COD})\left(\mathrm{L}^{\mathrm{NHC}}\right)\right]$ was used as $\operatorname{Ir}(\mathrm{I})$ precursor, whereas the reduction of $[\mathrm{IrCl}(\mathrm{COD})]_{2}$ under identical experimental conditions gave a black precipitate ( Ir $^{\text {black }}$ ) and a clear supernatant.

GC-MS analyses of both dichloromethane reaction solutions revealed the presence of cyclo-octane in solution, indicating that the hydrogenation of the COD ligand is mandatory for the $\operatorname{Ir}(\mathrm{I})$ reduction.

Ketjenblack ( $\mathrm{C}^{\mathrm{K}}$, surface area of $\left.1400 \mathrm{~m}^{2} / \mathrm{g}\right)$-supported Ir NPs were generated by evaporation of dichloromethane solutions of $\left[\operatorname{IrCl}(\mathrm{COD})\left(\mathrm{L}^{\mathrm{NHC}}\right)\right]$ and $[\operatorname{IrCl}(\mathrm{COD})]_{2}$ in the presence of $\mathrm{C}^{\mathrm{K}}$ (i.e. impregnation method). As a result, the isolated $\operatorname{Ir}(\mathrm{I})$-supported compounds $\left[\operatorname{IrCl}(\mathrm{COD})\left(\mathrm{L}^{\mathrm{NHC}}\right)\right] @ \mathrm{C}^{\mathrm{K}}$ and $[\operatorname{IrCl}(\mathrm{COD})]_{2} @ \mathrm{C}^{\mathrm{K}}$ were then suspended in water (i.e. water avoids lacking of the organometallic compound from the support) during the reduction step conducted at $418 \mathrm{~K}$ in the presence of hydrogen pressure (769 psi) (Scheme 1 ). After reduction, the black solids $\left(\mathrm{Ir}^{1} @ \mathrm{C}^{\mathrm{K}}\right.$ and $\left.\mathrm{Ir}^{2} @ \mathrm{C}^{\mathrm{K}}\right)$ were separated from water solution by centrifugation and dried under vacuum at $323 \mathrm{~K}$. The high surface area carbon support was chosen in order to avoid crystallization of the organometallic $\operatorname{Ir}(\mathrm{I})$ species on the support [39] and to prevent undesired interactions between

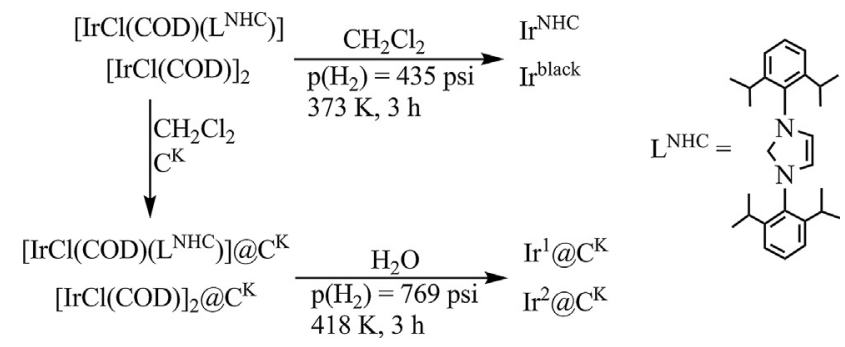

Scheme 1. Syntheses of Ir NPs upon reduction of $\operatorname{Ir}(\mathrm{I})$ complexes. 


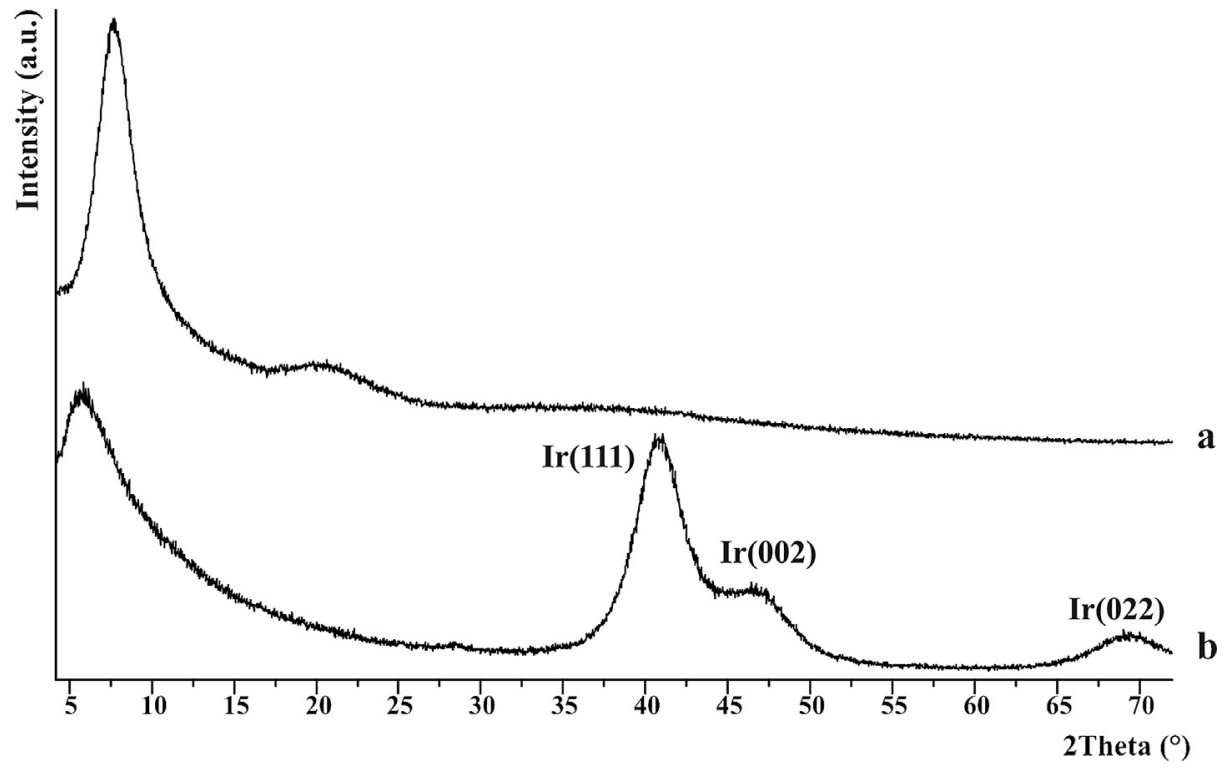

Fig. 1. PXRD spectra of $\operatorname{Ir}^{\mathrm{NHC}}(\mathrm{a})$ and $\operatorname{Ir}^{\text {black }}(\mathrm{b})$.

the functional groups of the support with the $\operatorname{Ir}(\mathrm{I})$ metal centre. In this context, carbon is much more suitable than an inorganic oxide as support.

\subsection{Catalysts' characterization}

A PXRD spectrum of isolated $\mathrm{Ir}^{\mathrm{NHC}}$ exhibited a broad Bragg reflex centered at $7.5^{\circ}(2 \Theta)$, which originated from the NHC ligand, whereas the corresponding spectrum of $\mathrm{Ir}^{\text {black }}$ showed the typical Bragg reflexes of fcc-iridium (Fig. 1, trace b). A Debye-Scherrer analysis of particle size, based on the Ir ( $\left.\begin{array}{lll}1 & 1 & 1\end{array}\right)$ Bragg reflex gave an average NPs' size of $2.5 \mathrm{~nm}$.

HAADF-STEM and high resolution HR-TEM analysis of $\mathrm{Ir}^{\mathrm{NHC}}$ (Fig. 2) clearly confirmed the presence of isolated and homogeneously dispersed Ir NPs featured by a mean diameter $\left(\mathrm{d}_{\mathrm{m}}\right)$ of $1.8 \mathrm{~nm}$. The efficient separation of the NPs from each other is due to the steric repulsion of NHC ligands located on different Ir NPs' surfaces $[47,48]$.

$\mathrm{Ir}^{\mathrm{NHC}}$ is completely soluble in most organic solvent, due to the high affinity of the NHC ligand with the latter solvents. Hence, ${ }^{1} \mathrm{H}$ and ${ }^{13} \mathrm{C}\left\{{ }^{1} \mathrm{H}\right\}$ NMR spectra of $\mathrm{Ir}^{\mathrm{NHC}}$ were acquired in $\mathrm{CDCl}_{3}$ (Figs. S1 and S2) showing broad NMR peaks in the chemical shift range expected for the carbene ligand. Particularly, the ${ }^{1} \mathrm{H}$ NMR signals assigned to the iso-propyl units of the NHC ligand were subject to broadening $[49,50]$. This spectroscopic result is the consequence of the close localization of the aromatic rings of the on the Ir NPs' surface (i.e. interaction of the NPs' surface and the aromatic rings [51]), bringing about a line broadening in the NMR spectra due to spin-spin relaxation and chemical shifts distribution originating from different binding sites on the metal NPs [52].

PXRD spectra of $\left[\operatorname{IrCl}(\mathrm{COD})\left(\mathrm{L}^{\mathrm{NHC}}\right)\right] @ \mathrm{C}^{\mathrm{K}}$ and $[\mathrm{IrCl}(\mathrm{COD})]_{2} @ \mathrm{C}^{\mathrm{K}}$ are identical, showing hence only the typical large Bragg reflexes for $\mathrm{C}^{\mathrm{K}}$ (Fig. S3) indicating hence the complete amorphous structure of the supported organometallic species deposited onto $C^{K}$ [39]. In order to prove the in-alteration of $\left[\operatorname{IrCl}(\mathrm{COD})\left(\mathrm{L}^{\mathrm{NHC}}\right)\right]$ upon impregnation with $\mathrm{C}^{\mathrm{K}},\left[\operatorname{IrCl}(\mathrm{COD})\left(\mathrm{L}^{\mathrm{NHC}}\right)\right] @ \mathrm{C}^{\mathrm{K}}$ was treated with $\mathrm{CDCl}_{3}$ in order to extract the organometallic compound from support. As a result, the corresponding ${ }^{1} \mathrm{H}$ NMR spectrum showed the same NMR pattern as the as-synthesized $\operatorname{Ir}(\mathrm{I})$ compound (Fig. S4), confirming the stability of the complex during the impregnation procedure. The PXRD spectra of $\operatorname{Ir}^{1} @ C^{K}$ and $\mathrm{Ir}^{2} @ C^{\mathrm{K}}$ showed only the pattern of $\mathrm{C}^{\mathrm{K}}$, indicating the small size of the Ir NPs obtained (Fig. S3).

HR-TEM micrographs of $\mathrm{Ir}^{1} @ \mathrm{C}^{\mathrm{K}}$ and $\mathrm{Ir}^{2} @ \mathrm{C}^{\mathrm{K}}$ revealed welldispersed Ir NPs' characterized by an average size of 1.4 and $1.2 \mathrm{~nm}$, respectively (Fig. 3). Irrespective of the organometallic
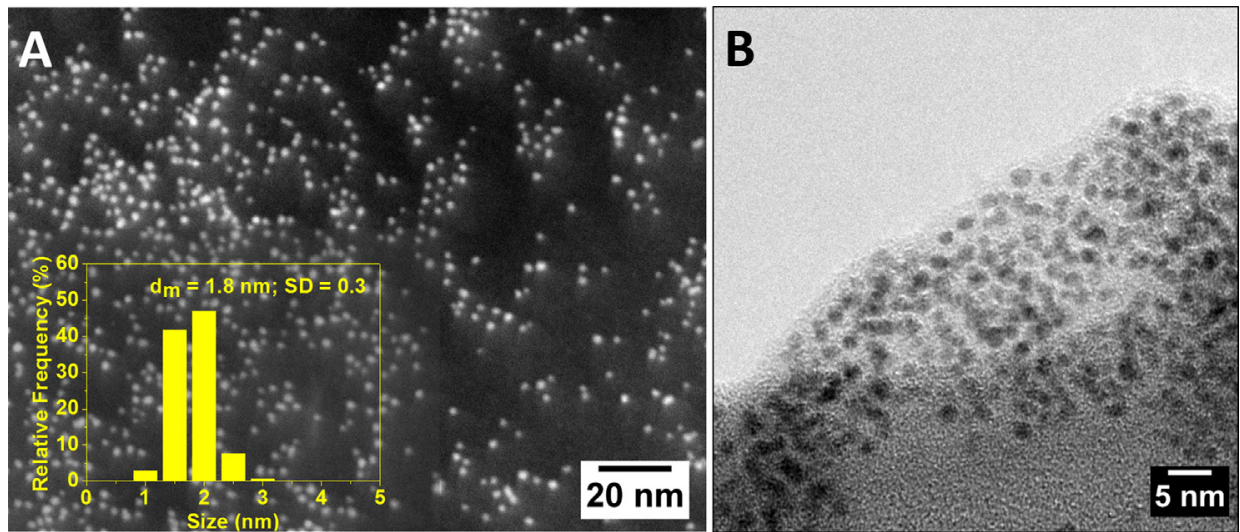

Fig. 2. Representative HAADF-STEM (A) HR-TEM (B) micrographs and histogram of particle size distribution of Ir ${ }^{\mathrm{NHC}}$ (A, inset). 

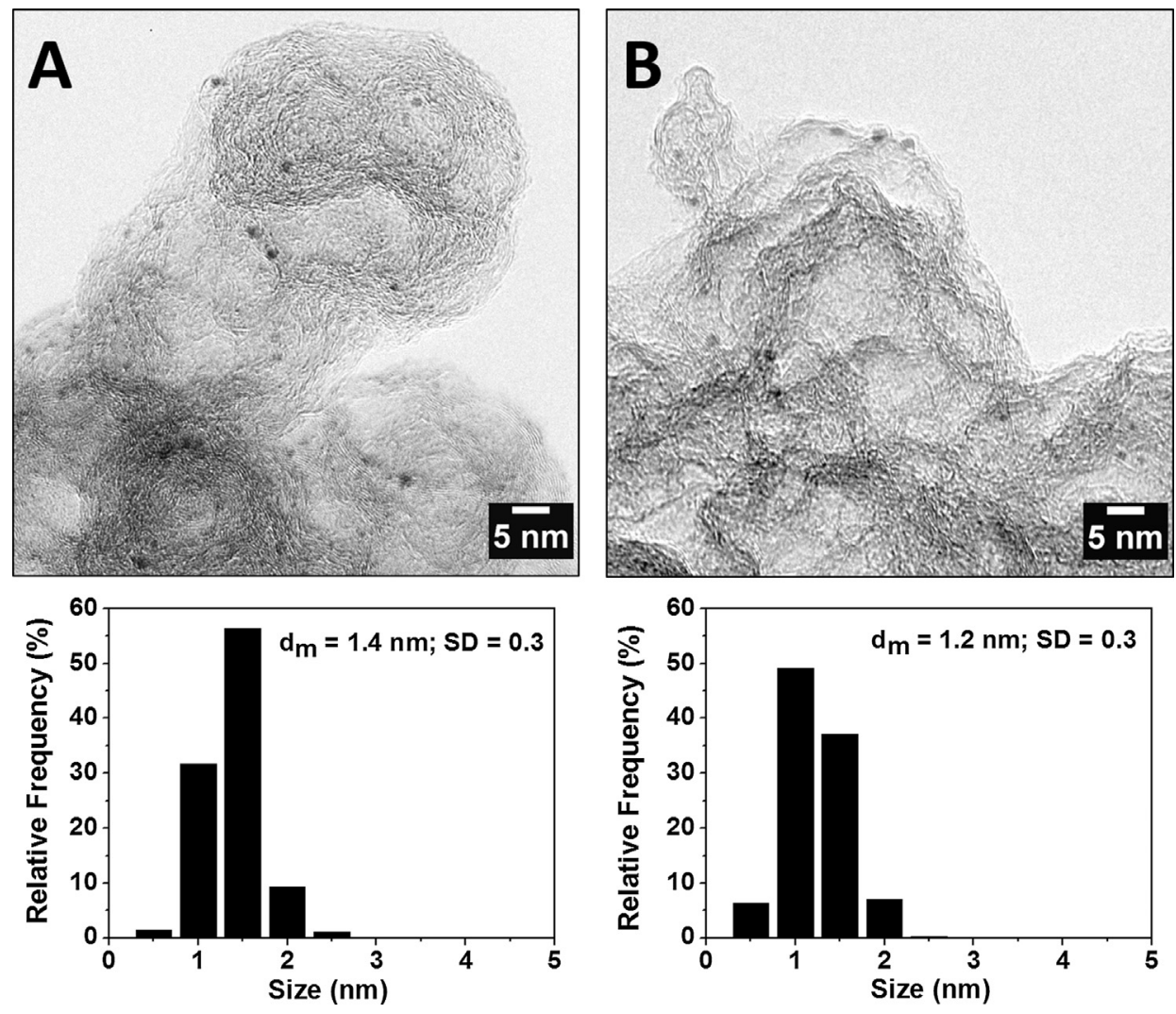

Fig. 3. Representative HR-TEM micrographs and relative histograms for as-synthesized $\operatorname{Ir}^{1} @ C^{\mathrm{K}}(A) a n d \mathrm{Ir}^{2} @ C^{\mathrm{K}}(B)$.

compound used to generate Ir NPs, the obtained supported Ir NPs' are of spherical shape.

ICP-OES analyses of the $\mathrm{C}^{\mathrm{K}}$-supported Ir NPs revealed an Ir content of 0.77 wt\% and 0.94 wt\% for $\operatorname{Ir}^{1} @ C^{K}$ and $\operatorname{Ir}^{2} @ C^{K}$, respectively.

XPS analyses carried out on $\operatorname{Ir}^{1 / 2} @ C^{K}$ confirmed the presence of $\operatorname{Ir}(0)$ (B.E. $\left.\left(4 \mathrm{f}_{7 / 2}\right) 60.8 \mathrm{eV},\left(\mathrm{Ir}^{1 / 2} @ \mathrm{C}^{\mathrm{K}}\right)\right)$, and $\operatorname{Ir}(\mathrm{IV})\left(\right.$ B.E. $\left(4 \mathrm{f}_{7 / 2}\right) 61.8 \mathrm{eV}$ $\left.\left(\operatorname{Ir}^{1 / 2} @ C^{K}\right)\right)$ (Fig. 4). The relative high abundance of metallic phase was reported in the literature for $2 \mathrm{~nm}$ sized Ir NPs on graphite nano-fibers [53] or for an Ir monolayer protected cluster [54]. The metallic state is dominant also in Pd and Pd-Ir nanoparticles [55]. The amount of metallic phase in $\operatorname{Ir}^{1 / 2} @ C^{\mathrm{K}}$ (i.e. $73 \pm 3 \%\left(\operatorname{Ir}^{1} @ C^{\mathrm{K}}\right.$ ) and $\left.60 \pm 3 \%\left(\operatorname{Ir}^{2} @ C^{K}\right)\right)$. The presence of $\operatorname{Ir}(I V)$ is due to the partial oxidation of the small Ir NPs in air atmosphere forming $\mathrm{IrO}_{2}$ $[44,56]$. The survey spectrum for $\operatorname{Ir}^{1} @ C^{\mathrm{K}}$ did not show the presence of nitrogen (N 1s), which we expected for the NPs' coordinating NHC ligand. Unfortunately, the very low amount of coordinated NHC ligand and the much lower (almost one eight) sensitivity factor of $\mathrm{N} 1 \mathrm{~s}$ compared to Ir $4 \mathrm{f}$ did not allow to detect the presence of nitrogen originating from NHC ligand.

\subsection{Catalysts' performance}

$\mathrm{Ir}^{\mathrm{NHC}}$ and $\mathrm{Ir}^{1 / 2} @ \mathrm{C}^{\mathrm{K}}$ were employed to catalyze the conversion of GLY into lactic acid (major product) in an autoclave under a nitrogen atmosphere using equimolar amounts of GLY and $\mathrm{NaOH}$ (i.e. one mol equivalent of base is required for a quantitative intramolecular Cannizzaro reaction to occur, step C in Scheme 2). $\mathrm{Ir}^{\mathrm{NHC}}$, which was not soluble in water due to the hydrophobicity of the NHC ligand was tested in 1,4-dioxane as reaction medium. The advantages in using 1,4-dioxane as solvent for $\mathrm{Ir}^{\mathrm{NHC}}$ catalyzed GLY to LA conversions consist in: $(i)$ the complete solubility of the catalyst in the reaction medium; (ii) the formation of a two phase system between 1,4-dioxane and GLY at room temperature, while

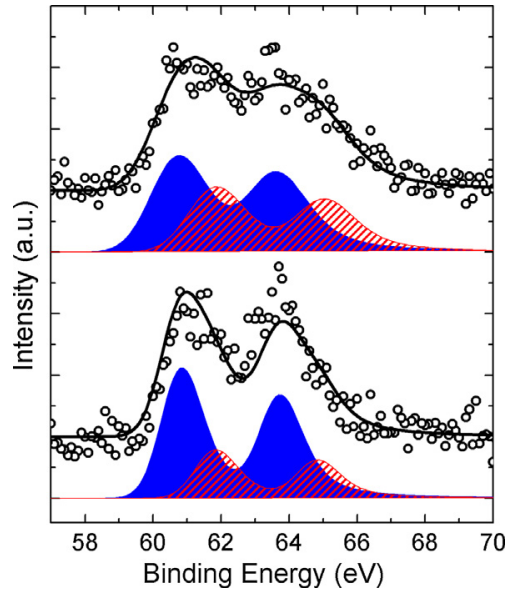

Fig. 4. Ir 4f XPS spectra of $\operatorname{Ir}^{1} @ C^{\mathrm{K}}$ (below) and $\mathrm{Ir}^{2} @ C^{\mathrm{K}}$ (above).

upon heating one phase is formed; (iii) the insolubility of sodium lactate ( $\mathrm{NaL}$, main reaction product) in 1,4-dioxane. As a consequence, the separation of the catalytic 1,4-dioxane solution from NaL and excess GLY consisted in a simple decantation step.

The organic reaction products formed during the $\mathrm{Ir}^{\mathrm{NHC}}$ and $\mathrm{Ir}^{1 / 2} @ \mathrm{C}^{\mathrm{K}}$-mediated GLY conversion in 1,4-dioxane and water, respectively, were LA (major product), 1,2-propandiol (1,2-PD), ethylene glycol (EG) and formic acid (FA) (Scheme 2). The results of the catalytic reactions are compiled in Table 1 and the reported TOF values are surface atom-related.

The $\mathrm{Ir}^{\mathrm{NHC}}$-catalyzed GLY conversion into NaL conducted in 1,4dioxane was extremely efficient, reaching a maximum TOF value of $9857 \mathrm{~h}^{-1}$ and a LA selectivity of $93.2 \%$ with respect to the liquid 


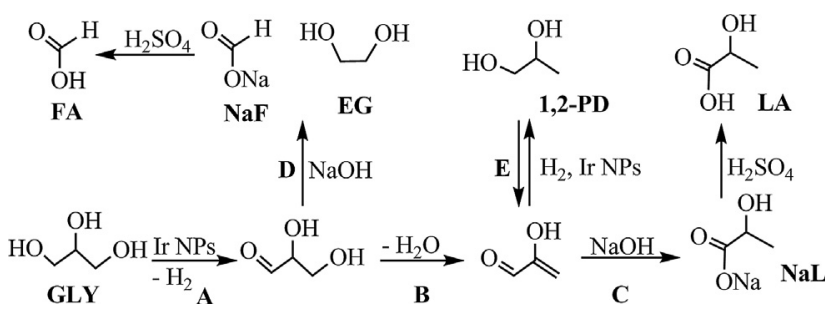

Scheme 2. Reaction pathways for the formation of the liquid reaction products in the Ir NP-catalyzed GLY conversion.

reaction products formed (Table 1 , entry 1 ). Almost complete GLY conversion was achieved after lasting the reaction for $8 \mathrm{~h}(98.0 \%$ GLY conversion) along with a small drop of LA selectivity to 91.0\% (Table 1 , entry 2 ), which is mainly due to an increased formation of 1,2-PD (i.e. an increase of the hydrogen pressure inside the autoclave fosters reaction step E, Scheme 2).

The catalytic performance of $\mathrm{Ir}^{\mathrm{NHC}}$ was maintained during three consecutive catalytic reactions (Table 1, entry 1 vs 3 and 4). In addition, $\mathrm{Ir}^{\mathrm{NHC}}$ led to an almost quantitative conversion of GLY to LA, avoiding almost complete formation of $\mathrm{CO}_{2}$ (i.e. $\mathrm{CO}_{2}$ is entrapped as carbonate during the catalytic reaction) which originated from metal-catalyzed C-C splitting reactions. The recovering of the catalyst consisted in decantation of the 1,4-dioxane solution of $\mathrm{Ir}^{\mathrm{NHC}}$ in air atmosphere. This latter catalytic solution was then reused to convert a fresh portion of GLY. The remaining highly viscous material was solubilized in water and then acidified with $\mathrm{H}_{2} \mathrm{SO}_{4}(0.1 \mathrm{M})$.

HPLC analyses conducted on the separated 1,4-dioxane and acidified water solutions showed that the former solution contained only trace amounts of 1,2-PD (Fig. S5), while the latter contained LA, not converted GLY, FA, 1,2-PD and trace amounts of 1,4dioxane (Fig. S6). The presence of low amounts of 1,2-PD in the recycled 1,4-dioxane solution did not alter the performance of the Ir-NPs confined in 1,4-dioxane. Gas phase analysis of the head space of the autoclave, prior to acidification of water solution, showed the presence of only hydrogen (Fig. S7).

In order to prove the effect of water in the $\mathrm{Ir}^{\mathrm{NHC}}$-catalyzed reaction, we performed a catalytic reaction in a $1: 2(\mathrm{v}: \mathrm{v})$ 1,4-dioxane water mixture, which gave significantly lower GLY conversion, and a lower yield $(62.0 \%)$ of liquid reaction products (Table 1, entry 5 ). In addition, in the course of the catalytic reaction Ir deposited inside the autoclave, which indicated a notable decomposition of the catalyst (i.e. loosing of the NPs' stabilizing NHC ligand) in the presence of water. Indeed the protonation of imidazol-2-yl carbenes by water showed a low barrier (i.e. the NHC carbene is $5.3 \mathrm{kcal} / \mathrm{mol}$ less stable compared to the imidazolium cation) [57]. On the other side, carbene-hydride coupling (i.e. reductive elimination of the carbene) giving the imidazolium ligand has been observed during the synthesis of NHC-stabilized metal NPs' [58].

The catalytic performance of $\mathrm{Ir}^{1 / 2} @ \mathrm{C}^{\mathrm{K}}$ in water as reaction medium was significantly lower compared to that of $\mathrm{Ir}^{\mathrm{NHC}}$ in 1,4dioxane (Table 1 , entry 6 vs 1 ), giving a much lower total GLY conversion. Unlike $\mathrm{Ir}^{\mathrm{NHC}}, \mathrm{Ir}^{1 / 2} @ \mathrm{C}^{\mathrm{K}}$ showed high conversion of GLY into gaseous products (i.e. $\mathrm{H}_{2}$ and $\mathrm{CO}_{2}$, which is trapped as carbonate, reducing hence the concentration of base in solution and as consequence the overall catalytic activity). Only $27.0 \%$ of the converted GLY were liquid reaction products (Table). In addition, $\mathrm{Ir}^{1 / 2} @ \mathrm{C}^{\mathrm{K}}$ exhibited higher hydrogenation activity for the tautomer of pyruvaldehyde (Scheme 2, step E), compared to Ir ${ }^{\mathrm{NHC}}$. Although, $\mathrm{Ir}^{1} @ \mathrm{C}^{\mathrm{K}}$ and $\mathrm{Ir}^{2} @ \mathrm{C}^{\mathrm{K}}$ exhibited comparable selectivity, which is indicating that catalytic active sites are of the same nature. In addition, $\operatorname{Ir}^{1} @$ $\mathrm{C}^{\mathrm{K}}$ showed a higher activity compared to $\mathrm{Ir}^{2} @ \mathrm{C}^{\mathrm{K}}$ (Table 1 , entries $6 / 7$ vs 8/9) and could hence be recycled without a significant decay of the catalytic performance.

A mass balance of $98 \%$ and $88-90 \%$ was found for $\mathrm{Ir}^{\mathrm{NHC}}$ and $\mathrm{Ir}^{1 / 2} @ \mathrm{C}^{\mathrm{K}}$, respectively.

HAADF-STEM analysis conducted on recovered $\mathrm{Ir}^{1 / 2} @ \mathrm{C}^{\mathrm{K}}$ showed for $\mathrm{Ir}^{2} @ \mathrm{C}^{\mathrm{K}}$ a more pronounced NP aggregation and size increase compared to $\mathrm{Ir}^{1} @ \mathrm{C}^{\mathrm{K}}$ leading to a prevalent population of iridium aggregates ranging from 3 to $7 \mathrm{~nm}$ in size (Fig. S8, image B). Accordingly, carefully acquired PXRD spectra for $\mathrm{Ir}^{1 / 2} @ \mathrm{C}^{\mathrm{K}}$ in the $2 \Theta$ range between 32.0 and $52.0^{\circ}$ (Fig. S9), showed for $\operatorname{Ir}^{1} @ C^{\mathrm{K}}$ a broad unresolved $\operatorname{Ir}\left(\begin{array}{lll}1 & 1 & 1\end{array}\right)$ Bragg reflex at $40.67^{\circ}(2 \Theta)$ : An Ir (1 111 )-based estimation of the average particle size by the Scherrer equation [41] (i.e. $40.67^{\circ}(2 \Theta)$, Full width at half maximum $(\mathrm{FWHM})=0.796^{\circ}, \mathrm{Cu} \mathrm{K} \alpha_{-}=1.54059 \AA$, shape factor $(\mathrm{K})=0.90$, Fig. S10) and using Si-powder as reference material), gave an average particle size of $18.0 \mathrm{~nm}$, which is much larger than the one observed for the most populated NPs' size, corroborating the polycrystallinity of the sample.

XPS analysis of recovered $\operatorname{Ir}^{1} @ C^{\mathrm{K}}$ showed a slightly higher percentage of $\operatorname{Ir}(0)$ on the NPs' surface compared to the assynthesized ones (i.e. $83 \pm 3 \%$ vs $73 \pm 3 \%$ )) (Fig. S8). This experimental data is in agreement with reducing reaction conditions (i.e. hydrogen formation during the catalytic GLY to LA conversion).

Table 1

GLY conversion catalyzed by $\mathrm{Ir}^{\mathrm{NHC}}$ and $\mathrm{Ir}^{1 / 2} @ \mathrm{C}^{\mathrm{K}}$.

\begin{tabular}{|c|c|c|c|c|c|c|c|c|}
\hline \multirow[b]{2}{*}{ Entry $^{\mathrm{a}}$} & \multirow[b]{2}{*}{ Catalyst } & \multirow[b]{2}{*}{$\mathrm{t}(\mathrm{h})$} & \multirow[b]{2}{*}{ Conv. GLY (\%)/TOF $\left(\mathrm{h}^{-1}\right)^{\mathrm{b}}$} & \multirow[b]{2}{*}{ Liquid prod. (\%) } & \multicolumn{4}{|c|}{ Sel. liquid prod. $(\%)^{\mathrm{c}}$} \\
\hline & & & & & LA & 1,2-PD & EG & FA \\
\hline \multicolumn{9}{|c|}{ Reactions in 1,4-Dioxane } \\
\hline 1 & $\mathrm{Ir}^{\mathrm{NHC}}$ & 3 & $55.2 / 9857$ & 54.0 & 93.2 & 4.2 & 1.8 & 0.8 \\
\hline 2 & $\mathrm{Ir}^{\mathrm{NHC}}$ & 8 & $98.0 / 6562$ & 92.0 & 91.0 & 6.0 & 2.3 & 0.7 \\
\hline $3^{d}$ & $\mathrm{Ir}^{\mathrm{NHC}}$ & 3 & $54.5 / 9732$ & 53.0 & 93.0 & 3.9 & 1.7 & 1.4 \\
\hline $4^{\mathrm{e}}$ & $\mathrm{Ir}^{\mathrm{NHC}}$ & 3 & $54.2 / 9678$ & 53.1 & 92.0 & 3.9 & 2.2 & 1.9 \\
\hline $5^{f}$ & $\mathrm{Ir}^{\mathrm{NHC}}$ & 3 & $45.2 / 8071$ & 28.0 & 90.0 & 6.5 & 2.0 & 1.5 \\
\hline \multicolumn{9}{|c|}{ Reactions in Water } \\
\hline 6 & $\mathrm{Ir}^{1} @ \mathrm{C}^{\mathrm{K}}$ & 5 & $46.7 / 4003$ & 12.7 & 89.0 & 7.7 & 1.8 & 1.5 \\
\hline $7^{e}$ & $\mathrm{Ir}^{1} @ \mathrm{C}^{\mathrm{K}}$ & 5 & $43.2 / 3703$ & 13.0 & 88.0 & 8.8 & 2.0 . & 1.2 \\
\hline 8 & $\mathrm{Ir}^{2} @ \mathrm{C}^{\mathrm{K}}$ & 5 & $29.0 / 2413$ & 7.3 & 87.0 & 12.5 & 0.4 & 0.1 \\
\hline $9^{\mathrm{e}}$ & $\mathrm{Ir}^{2} @ \mathrm{C}^{\mathrm{K}}$ & 5 & $18.0 / 1498$ & 6.5 & 86.5 & 11.7 & 1.4 & 0.4 \\
\hline
\end{tabular}

\footnotetext{
${ }^{a}$ Catalytic conditions: catalyst (Ir, $\left.5.6 \times 10^{-3} \mathrm{mmol}\right)$, GLY (156.0 mmol), NaOH $(156.0 \mathrm{mmol}), \mathrm{T} 418 \mathrm{~K}$, solvent $(30.0 \mathrm{~mL})$

b Surface atom-related TOF $\left(\mathrm{h}^{-1}\right)$.

c Selectivity of liquid products (\%).

d 1 st recycle.

e 3rd recycle.

f $1: 2$ (v:v) 1,4-dioxane water mixture.
} 


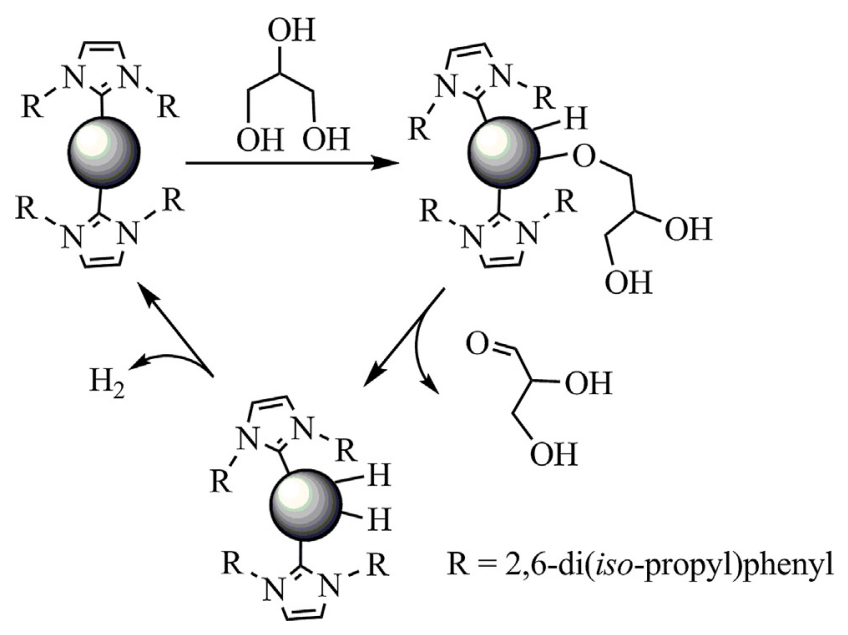

Scheme 3. Reaction sequence for the $\mathrm{Ir}^{\mathrm{NHC}}$-catalyzed conversion of GLY to glyceraldehyde.

ICP-OES analyses performed on the $\mathrm{Ir}^{1 / 2} @ \mathrm{C}^{\mathrm{K}}$-catalyzed reaction solutions gave in both cases a low Ir content of 1.02 ppm $\left(\operatorname{Ir}^{1} @ C^{K}\right)$ and $0.94 \mathrm{ppm}\left(\mathrm{Ir}^{2} @ \mathrm{C}^{\mathrm{K}}\right)$, which corresponded to a decrease of the original Ir content of 2.8 and 2.6\%, respectively. The separated water phase of the $\mathrm{Ir}^{\mathrm{NHC}}$-catalyzed reactions showed an Ir content $<0.1 \mathrm{ppm}$ (i.e. $<0.3 \%$ of the initial amount of Ir).

From a mechanistic point of view, the role of the surface coordinating $\mathrm{NHC}$ ligand in $\mathrm{Ir}^{\mathrm{NHC}}$ consisted in: $(i)$ solubilizing the $\mathrm{Ir}$ NPs in aprotic organic solvents, such as 1,4-dioxane and enabling the unsupported Ir NPs to be accessible from all sites, which is in contrast to supported NPs; (ii) steric blocking of the NPs' surface, allowing hence the NP-catalyzed GLY to glyceraldehyde conversion (Scheme 3), which comprises an oxidative addition of a terminal (i.e.primary) $\mathrm{OH}$ group of GLY, followed by the $\beta$-hydride elimination step and the concomitant release of glyceraldehydes. The catalytic cycle is closed by the release of hydrogen from the NPs' surface [59]. The C-C bond interaction with the Ir $^{\mathrm{NHC}}$ NPs' surface is sterically much more demanding compared to the dehydrogenation of GLY. As a result, C-C bond scission reactions, which are undesired in the GLY to LA conversion are fostered on naked Ir NPs (i.e. $\mathrm{Ir}^{2} @ \mathrm{C}^{\mathrm{K}}$ ) or those having a very low surface coverage with NHC ligands (i.e. $\operatorname{Ir}^{1} @ C^{K}$ ).

\section{Conclusion}

In conclusion, we found that $\left[\operatorname{IrCl}(\mathrm{COD})\left(\mathrm{L}^{\mathrm{NHC}}\right)\right]$ with $\mathrm{L}^{\mathrm{NHC}}=1,3-$ bis((2,6-di-isopropyl)phenyl)imidazol-2-ylidene was suitable to generate small Ir NPs (1.8 nm) decorated with $\mathrm{L}^{\mathrm{NHC}}\left(\mathrm{Ir}^{\mathrm{NHC}}\right)$ by using $\mathrm{CH}_{2} \mathrm{Cl}_{2}$ as solvent and hydrogen pressure as reducing agent. Attempts to synthesize the same type of NHC-stabilized Ir NPs' on a high surface area carbon support $\left(\mathrm{C}^{\mathrm{K}}\right)$ using water as reaction medium and hydrogen as reducing agent failed and gave almost naked Ir NPs $\left(\operatorname{Ir}^{1} @ C^{K}\right)$ of $1.4 \mathrm{~nm}$ in size were obtained.

1,4-Dioxane solutions of $\mathrm{Ir}^{\mathrm{NHC}}$ in the presence of glycerol (GLY) and $\mathrm{NaOH}$ in an 1:1 $\mathrm{M}$ ratio gave almost $98.0 \%$ liquid reaction products, of which lactic acid (LA) was formed with a selectivity of 93.0\%. The catalytic activity of $\operatorname{Ir}^{\mathrm{NHC}}$ (i.e. surface-atom-related TOF value of $10^{4} \mathrm{~h}^{-1}$ ) combined with the high selectivity for LA and easy recyclability (i.e. separation of the catalytic 1,4-dioxane solution from sodium lactate and excess GLY by simple decantation in air atmosphere) makes this catalytic system superior to the best known homogeneous catalysts of comparable LA selectivity $[10,11]$.
The high selectivity of $\mathrm{Ir}^{\mathrm{NHC}}$ in 1,4-dioxane for liquid reaction products is mainly due to the steric blocking of the NPs' surface, favoring the metal-catalyzed dehydrogenation of a terminal $\mathrm{OH}$ group of GLY, which requires only the interaction of a terminal $\mathrm{OH}$ group of GLY with the NPs' surface. In contrast, metalcatalyzed $\mathrm{C}-\mathrm{C}$ bond scission reactions need the interaction of C - C bonds with NPs' surface, which is sterically more demanding, and thus more favored on naked Ir NPs. In the absence of water the IrNHC catalytic system showed good stability under strong reducing conditions (i.e. presence of hydrogen) [60].

\section{Acknowledgments}

A. L. and A. K. acknowledge the European Union Horizon 2020 research and innovation program under the GrapheneCore2 785219-Graphene Flagship for funding.

\section{Appendix A. Supplementary material}

Supplementary data to this article can be found online at https://doi.org/10.1016/j.jcat.2018.10.024.

\section{References}

[1] P. Mäki-Arvela, I.L. Simakova, T. Salmi, D.Y. Murzin, Production of lactic acid/ lactate from biomass and their catalytic transformation, Chem. Rev. 114 (2014) 1909-1971.

[2] G. Bottari, K. Barta, Lactic acid and hydrogen from glycerol via acceptorless dehydrogenation using homogeneous catalysts, Recycl. Catal. 2 (2015) 70-77.

[3] M. Pagliaro, R. Ciriminna, H. Kimura, M. Rossi, C. Della Pina, From glycerol to value-added products, Angew. Chem. Int. Ed. 46 (2007) 4434-4440.

[4] C. Gunanathan, D. Milstein, Metal-ligand cooperation by aromatizationdearomatization: a new paradigm in bond activation and "green" catalysis, Acc. Chem. Res. 44 (2011) 588-602.

[5] M. Trincado, D. Banerjee, H. Grützmacher, Molecular catalysts for hydrogen production from alcohols, Energy Environ. Sci. 7 (2014) 2464-2503.

[6] G. Zeng, S. Sakaki, K. Fujita, H. Sano, R. Yamaguchi, Efficient catalyst for acceptorless alcohol dehydrogenation: interplay of theoretical and experimental studies, ACS Catal. 4 (2014) 1010-1020.

[7] G.B.W.L. Ligthart, R.H. Meijer, M.P.J. Donners, J. Meuldijk, J.A.J.M. Vekemans, L. A. Hulshof, Highly sustainable catalytic dehydrogenation of alcohols with evolution of hydrogen gas, Tetrahedron Lett. 44 (2003) 1507-1509.

[8] S. Muthaiah, S.H. Hong, Acceptorless and base-free dehydrogenation of alcohols and amines using ruthenium-hydride complexes, Adv. Synth. Catal. 354 (2012) 3045-3053.

[9] Y. Li, M. Nielsen, B. Li, P.H. Dixneuf, H. Junge, M. Beller, Ruthenium-catalyzed hydrogen generation from glycerol and selective synthesis of lactic acid, Green Chem. 17 (2015) 193-198.

[10] L.S. Sharinghausen, J. Campos, M.G. Manas, R.H. Crabtree, Efficient selective and atom economic catalytic conversion of glycerol to lactic acid, Nat. Commun. 5 (2014) 5084-5092.

[11] Z. Lu, I. Demianets, R. Hamze, N.J. Terrile, T.J. Williams, A prolific catalyst for selective conversion of neat glycerol to lactic acid, ACS Catal. 6 (2016) 20142017.

[12] D. Bourissou, O. Guerret, F.P. Gabbaï, G. Bertrand, Stable carbenes, Chem. Rev. 100 (2000) 39-91.

[13] S. Würtz, F. Glorius, Surveying sterically demanding N-heterocyclic carbene ligands with restricted flexibility for palladium-catalyzed cross-coupling reactions, Acc. Chem. Res. 41 (2008) 1523-1533.

[14] C. Richter, K. Schaepe, F. Glorius, B.J. Ravoo, Tailor-made N-heterocyclic carbenes for nanoparticle stabilization, Chem. Commun. 50 (2014) 3204-3207.

[15] J. Crespo, Y. Guari, A. Ibarra, J. Larinova, T. Lasanta, D. Lauencin, J.M. López-deLuzuriaga, M. Monge, M.E. Olmos, S. Richeter, Ultrasmall NHC-coated gold nanoparticles obtained through solvent free thermolysis of organometallic $\mathrm{Au}$ (I) complexes, Dalton Trans. 43 (2014) 15713-15718.

[16] P. Lara, O. Rivada-Wheelaghan, S. Conejero, R. Poteau, K. Philippot, B. Chaudret Ruthenium nanoparticles stabilized by N-heterocyclic carbenes: ligand location and influence on reactivity, Angew. Chem. Int. Ed. 50 (2011) 1208012084.

[17] J. Vignolle, T. Don Tilley, N-Heterocyclic carbene-stabilized gold nanoparticles and their assembly into 3D superlattices, Chem. Commun. (2009) 7230-7232.

[18] A.V. Zhukhovitskiy, M.G. Mavros, T. Van Voorhis, J.A. Johnson, Addressable carbene anchors for gold surfaces, J. Am. Chem. Soc. 135 (2013) 7418-7421.

[19] X. Ling, N. Schaeffer, S. Roland, M.-P. Pileni, Nanocrystals: why do silver and gold N-heterocyclic carbene precursors behave differently?, Langmuir 29 (2013) 12647-12656

[20] E.C. Hurst, K. Wilson, I.J.S. Fairlamb, V. Chechik, N-heterocyclic carbene coated metal nanoparticles, New J. Chem. 33 (2009) 1837-1840. 
[21] M. Diaz de los Bernardos, S. Pérez-Rodriguez, A. Gual, C. Claver, C. Godard, Facile synthesis of NHC-stabilized $\mathrm{Ni}$ nanoparticles and their catalytic application in the Z-selective hydrogenation of alkynes, Chem. Commun. 53 (2017) 7894-7897.

[22] S. Roland, X. Ling, M.-P. Pileni, N-heterocyclic carbene ligands for Au nanocrystal stabilization and three-dimensional self-assembly, Langmuir 32 (2016) 7683-7696.

[23] J. Campos, L.S. Sharninghausen, R.H. Crabtree, D. Balcells, A carbene-rich but carbonyl-poor $\left[\mathrm{Ir}_{6}(\mathrm{IMe})_{8}(\mathrm{CO})_{2} \mathrm{H}_{14}\right]^{2+}$ polyhydride cluster as a deactivation product from catalytic glycerol dehydrogenation, Angew. Chem. Int. Ed. 53 (2014) 12808-12811.

[24] A. Azua, J.A. Mata, E. Peris, F. Lamaty, J. Martinez, E. Colacino, Alternative energy input for transfer hydrogenation using iridium NHC based catalysts in glycerol as hydrogen donor and solvent, Organometallics 31 (2012) 3911 3919.

[25] Z. Sun, Y. Liu, J. Chen, C. Huang, T. Tu, Robust iridium coordination polymers: highly selective, efficient and recyclable catalysts for oxidative conversion of glycerol to potassium lactate with dihydrogen liberation, ACS Catal. 5 (2015) 6573-6578.

[26] N. Razali, A.Z. Abdullah, Production of lactic acid from glycerol via chemical conversion using solid catalyst: a review, Appl. Catal. A Gen. 543 (2017) 234246.

[27] T. Komanoya, A. Suzuki, K. Nakajima, M. Kitano, K. Kamata, M. Hara, A combined catalyst of Pt nanoparticles and $\mathrm{TiO}_{2}$ with water-tolerant Lewis acid sites for one-pot conversion of glycerol to lactic acid, ChemCatChem 8 (2016) 1094-1099.

[28] M. Tao, X. Yi, I. Delidovich, R. Palkovits, J. Shi, X. Wang, Heteropolyacidcatalyzed oxidation of glycerol into lactic acid under mild base-free conditions, ChemSusChem 8 (2015) 4195-4201.

[29] J. Xu, H. Zhang, Y. Zhao, B. Yu, S. Chen, Y. Li, L. Hao, Z. Liu, Selective oxidation of glycerol to lactic acid under acidic conditions using AuPd/TiO 2 catalyst, Green Chem. 15 (2013) 1520-1525.

[30] H.J. Cho, C.-C. Chang, W. Fan, Base free, one-pot synthesis of lactic acid from glycerol using a bifunctional Pt/Sn-MFI catalyst, Green Chem. 16 (2014) 34283433.

[31] Y. Shen, S. Zhang, H. Li, Y. Ren, H. Liu, Efficient synthesis of lactic acid by aerobic oxidation of glycerol on Au-Pt/TiO 2 catalyst, Chem. Eur. J. 16 (2010) $7368-7371$

[32] R.K.P. Purushothaman, J. van Haveren, D.S. van Es, I. Melián-Cabrera, J.D. Meeldijk, H.J. Heeres, An efficient one pot conversion of glycerol to lactic acid using bimetallic gold-platinum catalysts on a nanocrystalline $\mathrm{CeO}_{2}$ support, Appl. Catal. B: Environ. 147 (2014) 92-100.

[33] W. Oberhauser, C. Evangelisti, C. Tiozzo, F. Vizza, R. Psaro, Lactic acid from glycerol by ethylene-stabilized platinum nanoparticles, ACS Catal. 6 (2016) $1671-1674$.

[34] F. Auneau, S. Noël, G. Aubert, M. Besson, L. Djakovitch, C. Pinel, On the role of the atmosphere in the catalytic glycerol transformation over iridium-based catalysts, Catal. Commun. 16 (2011) 144-149.

[35] P. Lakshmanan, P.P. Upare, N.-T. Le, Y.K. Hwang, D.W. Hwang, U. Hwang Lee, H. R. Kim, J.-S. Chang, Facile synthesis of $\mathrm{CeO}_{2}$-supported gold nanoparticle catalysts for selective oxidation of glycerol into lactic acid, Appl. Catal. A: Gen. 468 (2013) 260-268.

[36] C. Zhang, T. Wang, X. Liu, Y. Ding, Cu-promoted Pt-activated carbon catalyst for glycerol oxidation to lactic acid, J. Mol. Catal. A: Chem. 424 (2016) 91-97.

[37] J. Ftouni, N. Villandier, F. Auneau, M. Besson, L. Djakovitch, C. Pinel, From glycerol to lactic acid under inert conditions in the presence of platinum-based catalysts: the influence of support, Catal. Today 257 (2015) 267-273.

[38] X. Jin, D. Roy, P.S. Thapa, R.V. Subramaniam, Chaudhari, Atom economical aqueous-phase conversion (APC) of biopolyols to lactic acid, glycols, and linear alcohols using supported metal catalysts, ACS Sust. Chem. Eng. 1 (2013) $1453-$ 1462.

[39] M. Bevilacqua, C. Bianchini, A. Marchionni, J. Filippi, A. Lavacchi, H. Miller, W. Oberhauser, F. Vizza, G. Granozzi, L. Artiglia, S.P. Annen, F. Krumeich, H. Grützmacher, Improvement in the efficiency of an OrganoMetallic fuel cell by tuning the molecular architecture of the anode electrocatalyst and the nature of the carbon support, Energy Environ. Sci. 5 (2012) 8608-8620.

[40] R.A. Kelly, H. Clavier, S. Giudice, N.M. Scott, E.D. Stevens, J. Bordner, I. Samardjiev, C.D. Hoff, L. Cavallo, S.P. Nolan, Determination of N-heterocyclic carbene (NHC) steric and electronic parameters using the $\left[(\mathrm{NHC}) \operatorname{Ir}(\mathrm{CO})_{2} \mathrm{Cl}\right]$ system, Organometallics 27 (2008) 202-210.

[41] A.L. Patterson, The Scherrer formula for X-ray particle size determination, Phys. Rev. 56 (1939) 978-982.

[42] M. Borodziński, M. Bonarowska, Relation between crystallite size and dispersion on supported metal catalysts, Langmuir 13 (1997) 5613-5620.

[43] H.Y. Hall, P.M.A. Sherwood, X-ray photoelectron spectroscopic studies of the iridium electrode system, J. Chem. Soc. Faraday Trans. 80 (1984) 135-152.

[44] V. Pfeifer, T.E. Jones, J.J. Velasco Vélez, C. Massué, R. Arrigo, D. Teschner, F. Girgsdies, M. Scherzer, M.T. Greiner, J. Allan, M. Hashagen, G. Weinberg, S. Piccinin, M. Hävecker, A. Knop-Gericke, R. Schlögl, The electronic structure of iridium and its oxides, Surf. Interface Anal. 48 (2016) 261-273.

[45] N. Fairley, A. Carrick, The Casa cookbook: Recipes for XPS data processing, Acolyte Science, Knutsford, 2005.

[46] M. Di Sabatino, A.L. Dons, J. Hinrichs, L. Arnberg, Determination of relative sensitivity factors for trace element analysis of solar cell silicon by fast-flow glow discharge mass spectrometry, Spectrochimica Acta Part B 66 (2011) 144148.

[47] W. Wu, E.V. Shevchenko, The surface science of nanoparticles for catalysis: electronic and steric effects of organic ligands, J. Nanopart. Res. 20 (2018) 255.

[48] A.J. Worthen, V. Tran, K.A. Cornell, T.M. Truskett, K.P. Johnston, Steric stabilization of nanoparticles with grafted low molecular weight ligands in highly concentrated brines including divalent ions, Soft Matter 12 (2016) 2025-2039.

[49] E.A. Baquero, S. Tricard, J.C. Flores, E. De Jesús, B. Chaudret, Highly stable water-soluble platinum nanoparticles stabilized by hydrophilic $\mathrm{N}$-heterocyclic carbenes, Angew. Chem. Int. Ed. 53 (2014) 13220-13224.

[50] K.-S. Kim, D. Demberelnyamba, H. Lee, Size-selective synthesis of gold and platinum nanoparticles using novel thiol-functionalized ionic liquids, Langmuir 20 (2004) 556-560.

[51] P. Lara, A. Suárez, V. Collière, K. Philippot, B. Chaudret, Platinum N-heterocyclic carbene nanoparticles as new and effective catalysts for the selective hydrogenation of nitroaromatics, ChemCatChem 6 (2014) 87-90.

[52] A.C. Templeton, W.P. Wuelfing, R.W. Murray, Monolayer-protected cluster molecules, Acc. Chem. Res. 33 (2000) 27-36.

[53] S. Gouse Peera, A.K. Sahu, S.D. Bhat, S.C. Lee, Nitrogen functionalized graphite nanofibers/Ir nanoparticles for enhanced oxygen reduction reaction in polymer electrolyte fuel cells (PEFCs), RSC Adv. 4 (2014) 11080-11088.

[54] S. Bhat, I. Chakraborty, T.A. Maark, A. Mitra, G. De, T. Pradeep, Atomically precise and monolayer protected iridium clusters in solution, RSC Adv. 6 (2016) 26679-26688.

[55] H. Ziaei-azad, C.-X. Yin, J. Shen, Y. Hu, D. Karpuzov, N. Semagina, Size- and structure-controlled mono- and bimetallic Ir-Pd nanoparticles in selective ring opening of indan, J. Catal. 300 (2013) 113-124.

[56] S.J. Freakley, J. Ruiz-Esquius, D.J. Morgan, The X-ray photoelectron spectra of Ir, $\mathrm{IrO}_{2}$ and $\mathrm{IrCl}_{3}$ revisited, Surf. Interface Anal. 49 (2017) 794-799.

[57] T.L. Amyes, S.T. Diver, J.P. Richard, F.M. Rivas, K. Toth, Formation and stability of $\mathrm{N}$-heterocyclic carbenes in water: the carbon acid $\mathrm{pK}_{\mathrm{a}}$ of imidazolium cations in aqueous solution, J. Am. Chem. Soc. 126 (2004) 4366-4374.

[58] J.M. Asenio, S. Tricard, Y. Coppel, R. Andrés, B. Chaudret, E. de Jesús, Synthesis of water-soluble palladium nanoparticles stabilized by sulfonated Nheterocyclic carbenes, Chem. Eur. J. 23 (2017) 13435-13444.

[59] K. Mori, T. Hara, T. Mizugaki, K. Ebitani, K. Kaneda, Hydroxyapatite-supported palladium nanoclusters: a highly active heterogeneous catalyst for selective oxidation of alcohols by use of molecular oxygen, J. Am. Chem. Soc. 126 (2004) 10657-10666.

[60] D. Gonzalez-Galvez, P. Lara, O. Rivada-Wheelaghan, S. Conejero, B. Chaudret, K. Philippot, P.W.N.M. van Leeuwen, NHC-stabilized ruthenium nanoparticles as new catalysts for the hydrogenation of aromatics, Catal. Sci. Technol. 3 (2013) 99-105. 